\title{
An estimate of glacier mass balance for the Chandra basin, western Himalaya, for the period 1984-2012
}

\author{
Sayli Atul TAWDE, ${ }^{1}$ Anil V. KULKARNI, ${ }^{2}$ Govindasamy BALA ${ }^{1,2,3}$ \\ ${ }^{1}$ Center for Atmospheric and Oceanic Sciences, Indian Institute of Science, Bangalore, India. \\ E-mail: saylitawde@gmail.com \\ ${ }^{2}$ Divecha Centre for Climate Change, Indian Institute of Science, Bangalore, India \\ ${ }^{3}$ Interdisciplinary Centre for Water Research, Indian Institute of Science, Bangalore, India
}

\begin{abstract}
An improved understanding of fresh water stored in the Himalaya is crucial for water resource management in South Asia and can be inferred from glacier mass-balance estimates. However, field investigations in the rugged Himalaya are limited to a few individual glaciers and short duration. Therefore, we have recently developed an approach that combines satellite-derived snowlines, a temperature-index melt model and the accumulation-area ratio method to estimate annual mass balance of glaciers at basin scale and for a long period. In this investigation, the mass balance of 146 glaciers in the Chandra basin, western Himalaya, is estimated from 1984 to 2012. We estimate the trend in equilibrium line altitude of the basin as $+113 \mathrm{~m}$ decade $^{-1}$ and the mean mass balance as $-0.61 \pm 0.46 \mathrm{~m}$ w.e. $\mathrm{a}^{-1}$. Our basin-wide mass-balance estimates are in agreement with the geodetic method during 1999-2012. Sensitivity analysis suggests that a $20 \%$ increase in precipitation can offset changes in mass balance for a $1{ }^{\circ} \mathrm{C}$ temperature rise. A water loss of $18 \%$ of the total basin volume is estimated, and $67 \%$ for small and low-altitude glaciers during 1984-2012, indicating a looming water scarcity crisis for villages in this valley.
\end{abstract}

KEYWORDS: climate change, glacier mass balance, mountain glaciers

\section{INTRODUCTION}

The glaciers in the Himalaya constitute the third largest ice mass in the world after the Arctic and Antarctic regions. Rivers originating from these glaciers are the primary source of water to the population downstream. The amount and timing of melt from these glaciers are strongly related to local precipitation and temperature (Barnett and others, 2005). Recent studies in the Himalaya suggest that glacier melting could accelerate in the future due to climate change (Immerzeel and others, 2012; Chaturvedi and others, 2014; Lutz and others, 2014; Shea and others, 2015). The persistent mass loss of the glaciers could lead to retreat in glacier area until a new equilibrium with climate is achieved. It will further affect runoff from the glaciers, i.e. runoff may increase during the initial decades of climate warming and then decline near the end of the century (Huss and others, 2008; Immerzeel and others, 2012). In addition to changing climate, the growing population of the region also demands a proper management of water resources. Therefore, knowledge of annual variations in glacier-stored water is important for planning water resource management in this region. Trends and variability in glacier-stored water can be inferred by monitoring glacier mass balance at basin scale in conjunction with local climate.

Mass balance is a measure of difference between the input and output of water stored in a glacier over a balance year (Paterson, 2000). Hence, mass-balance information on multiple spatial and temporal scales can provide a perspective on glacier interactions with hydrology and climatology in mountainous terrain. There are direct and indirect methods of estimating glacier mass balance. Direct measurements of mass balance are glacier-specific. Indirect measurement methods such as geodetic, gravimetric and accumulation-area ratio (AAR) are widely used to analyse mass balance at larger scales in the Himalaya (Kulkarni and others, 2004; Berthier and others, 2007; Matsuo and Heki, 2010; Brahmbhatt and others, 2011; Gardelle and others, 2013; Vincent and others, 2013; Mir and others, 2014). Among these, the geodetic method is often used to estimate regionwide long-term mass balance (Berthier and others, 2007; Gardelle and others, 2013; Vincent and others, 2013; Vijay and Braun, 2016). However, the geodetic method has limitations: it may not produce annual variations in mass balance due to uncertainties and availability of digital elevation models (DEMs). The satellite-based gravitational method can provide annual mass balance for a large area but with coarser spatial resolution $(\sim 400 \mathrm{~km})$. The AAR method provides an option to calculate mass balance with a higher temporal resolution at individual glaciers, which can then be scaled up to provide basin-wide mass budget. However, cloud cover, sporadic snowfalls and data gaps in satellite images hamper the mass-balance estimates using the AAR method (Kulkarni, 1996; Rabatel and others, 2005; Tawde and others, 2016).

To circumvent the challenge of locating equilibrium line altitude (ELA) in the AAR method, Tawde and others (2016) have suggested a new approach. The improved AAR method discussed by Tawde and others (2016) models annual changes in ELA (altitude where the total melt and accumulation over a balance year are equal) using snowfall measurements and a temperature-index ( $\mathrm{TI})$ model. The model-derived annual ELA and AAR are then used to estimate specific mass balances of glaciers by employing the AAR/mass-balance relationship for the basin. Compared with the traditional AAR method, the method discussed by Tawde and others (2016) reduces the bias between modelled and field mass-balance estimates by up to $50.44 \%$. 
In Tawde and others (2016), we have applied and tested the improved AAR method for a few glaciers in the Chandra basin. In the present analysis, we extend the method to the entire basin. One can use the more complex enhanced temperature-index (ETI) or energy-balance (EB) models instead of the TI model to estimate snowmelt (Hock, 1999; Pellicciotti and others, 2005; Favier and others, 2011; Carenzo, 2012). However, previous studies have found that the improvement in melt estimates using ETI models is not significant and both ETI and EB models need more in situ input data and parameters from glaciers to estimate melt (Blard and others, 2011; Gabbi and others, 2014). Therefore, the TI model is preferred in the present study because of its efficiency in estimating melt with simple computations and minimal input requirements. The main goal of this study is to use the improved AAR method and estimate mass balance at larger spatial scale over a period of 28 years. We compare our model-derived mass balance with the geodetic method at basin scale and with the regional-global glacier mass-balance trends. The sensitivity of basin-wide mass balance to climate is also discussed. Further, we estimate the glacier ice volume to examine glacier-stored water in the basin.

\section{STUDY AREA}

The Chandra basin is located in the Lahaul-Spiti district, western Himalaya, India. The basin covers an area of $2.44 \times 10^{3} \mathrm{~km}^{2}$ with elevation extending from 2800 to $6600 \mathrm{~m}$ a.s.l. The glaciated area of the basin is $703.64 \mathrm{~km}^{2}$, i.e. $\sim 30 \%$ of the total basin area (Sangewar and Shukla, 2009). There are 201 glaciers in the basin, only five of which have an area $>20 \mathrm{~km}^{2}$ (Fig. 1). The basin consists of valley- and mountain-type glaciers. Most of the glaciers in the basin face north, northeast and northwest. The mean slope of glaciers in the basin is $\sim 21^{\circ}$. The meteorological station near the basin suggests that the basin climate is influenced by both western disturbances in the winter and monsoon circulation in the summer (see Supplementary information). However, glaciers in the basin predominantly receive accumulation in the form of snow in the winter (October to April) (Azam and others, 2014b; Tawde and others, 2016).

\section{DATA}

The implementation of the mass-balance model described by Tawde and others (2016) requires daily/monthly measurements of temperature and precipitation at a nearby station. In the present study, daily minimum, maximum air temperature and snowfall from 1984 to 2012 are obtained from Kaza weather station (3600 m a.s.I.). Both the Chandra basin and Kaza station are located in the orogenic interior of the Himalaya. The station is $\sim 25 \mathrm{~km}$ from the basin boundary (Fig. 1). Climatologically averaged annual temperature at Kaza is $3.2{ }^{\circ} \mathrm{C}$ and precipitation is $1.34 \mathrm{~mm} \mathrm{~d}^{-1}$. Other variables, such as temperature lapse rates and snow densities for calculating melt factors, are obtained from observations made at the Patseo (Snow Avalanche and Study Establishment, SASE) observatory in the same valley (Table 1). Estimated lapse rates $\left(7.7-9.1^{\circ} \mathrm{C} \mathrm{km}^{-1}\right)$ are higher than the moist adiabatic lapse rate $\left(\sim 6.5^{\circ} \mathrm{C} \mathrm{km}^{-1}\right)$ because there is likely less water vapour at high altitudes in the orogenic interior of the Himalaya. The precipitation gradient is taken from Tawde and others (2016) and is derived using data on 12 glaciers in the basin (Fig. 1).

The glacier boundaries used in the present analysis are from the Randolph Glacier Inventory version 5 (RGI v5). According to the inventory, the area of polygons in the basin ranges from 0.05 to $112.36 \mathrm{~km}^{2}$. However, to reduce

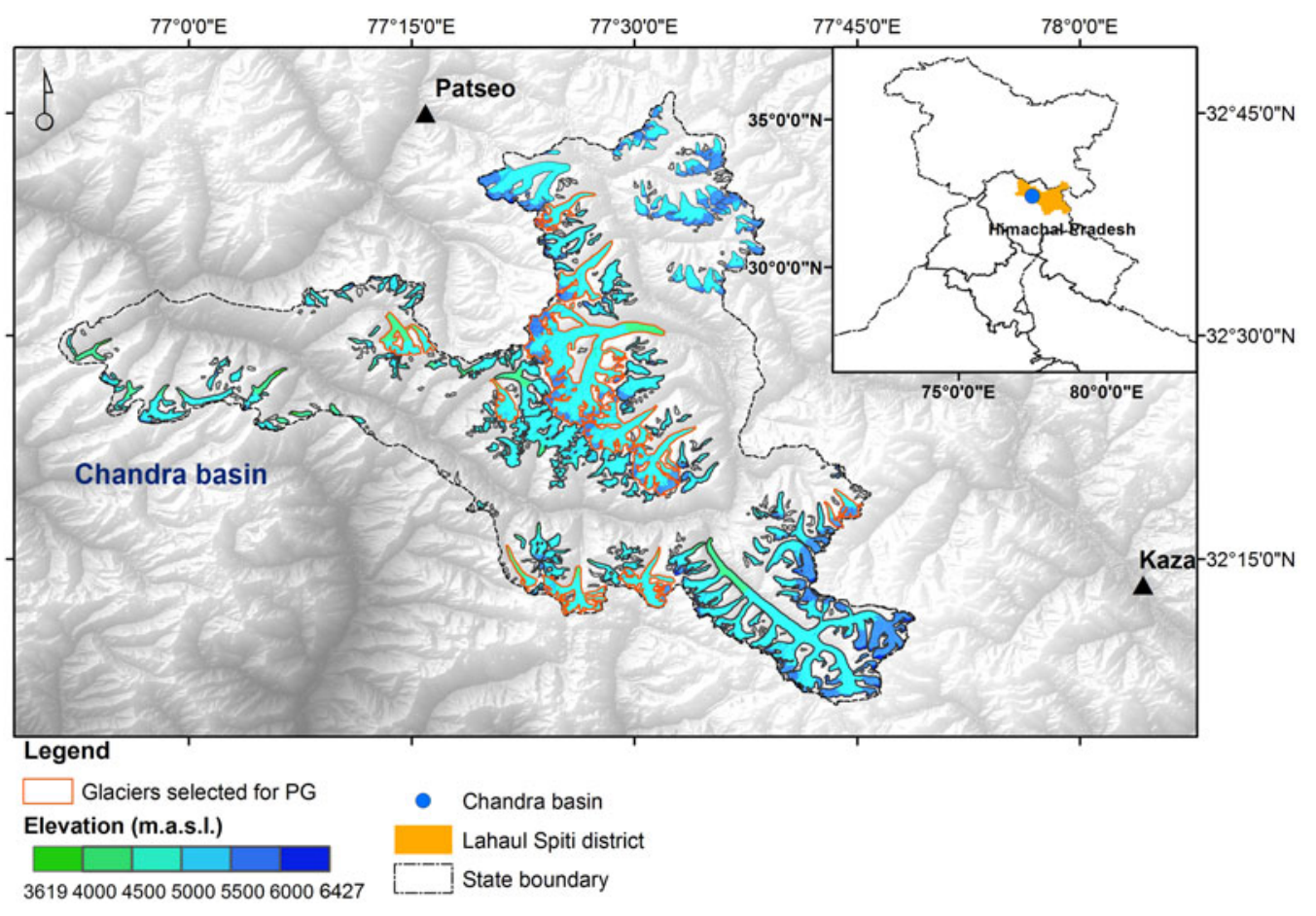

Fig. 1. Geographical location of the Chandra basin, Lahual-Spiti district, Himachal Pradesh. The triangle represents meteorological stations, i.e. Kaza and Patseo (Snow Avalanche and Study Establishment) station. The selected glaciers (area $>0.5 \mathrm{~km}^{2}$ ) are shown with black borders. The glaciers selected for calculation of precipitation gradient by Tawde and others (2016) are shown in the orange boundary. 
Table 1. List of input parameters used for the Chandra basin

\begin{tabular}{ll}
\hline Parameter & Values used \\
\hline Elevation $(\mathrm{m}$ a.s.I.) & $3625-6425$ \\
Lapse rate $\left({ }^{\circ} \mathrm{C} \mathrm{km}\right.$ & \\
& 7.7 (MAM) \\
& 7.9 (J) $)$ \\
Snowmelt factor $\left(\mathrm{mm}^{\circ} \mathrm{C}^{-1} \mathrm{~d}^{-1}\right)$ & 9.1 (SON) \\
Precipitation gradient $\left(\% \mathrm{~m}^{-1}\right)$ & $2.31-3.85$ \\
& 0.19
\end{tabular}

The parameters are adopted from Tawde and others (2016).

uncertainty in discrimination of glaciers and perennial snow, only polygons with an area $>0.5 \mathrm{~km}^{2}$ (146 glaciers out of 201) are selected. These glaciers account for $93 \%$ of the total glaciated area in the basin, so the exclusion of remaining polygons (area $<0.5 \mathrm{~km}^{2}$ ) in our analysis is unlikely to alter the basin-wide mass balance. The topographic information on the selected glaciers is calculated from the Advanced Spaceborne Thermal Emission and Reflection Radiometer (ASTER) Global DEM.

\section{METHODOLOGY}

In the present analysis, we estimate (1) the glacier mass balance of the Chandra basin from balance year 1984/85 to $2011 / 12$ (hereafter referred as 1984-2012), (2) the sensitivity of basin-wide mass balance to climate variables and (3) the volume of water stored in the basin.

\section{Model description}

We estimate basin-wide mass balance using the improved AAR method discussed in detail in Tawde and others (2016). Here we provide only a brief description of the method. The approach involves two major steps: (i) estimation of ELA using climate data and (ii) estimation of glacier mass balance using the AAR/mass-balance relationship.

The position of the ELA is estimated by monitoring the position of transient snowlines throughout the ablation season. To model the movement of the snowline, we need the altitudinal distribution of snowmelt and accumulation during the balance year. The altitudinal distribution of ablation at every $50 \mathrm{~m}$ elevation interval on glaciers is estimated using the TI model. At any altitude $j$, the cumulative snow ablation $M_{j}(\mathrm{~mm})$ is given by

$$
M_{j}=\sum_{i=1}^{n} F_{\text {snow }, i, j} \times \operatorname{PDD}_{i, j}
$$

where $\mathrm{PDD}_{i, j}$ is positive degree-days $\left({ }^{\circ} \mathrm{C}\right)$ and $F_{\text {snow }, i, j}$ is snowmelt factor $\left(\mathrm{mm}^{\circ} \mathrm{C}^{-1} \mathrm{~d}^{-1}\right)$ on the $i$ th day at the $j$ th elevation zone. Snowmelt factors increase as temperatures increase above freezing point at respective elevation zones (Table 1). The summation in Eqn (1) is over all days ( 1 to $n$ ) in summer (May to September). May is included in the summer season because, occasionally, disappearances of snow at glacier tongues are observed in the basin at the end of May.

The altitudinal accumulation $\left(\mathrm{Acc}_{j}\right)$ of snow at different elevation zones $(j)$ is simulated using snowfall observations and vertical precipitation gradient as follows:

$$
\mathrm{Acc}_{j}=\sum_{i=1}^{m}\left(P_{\mathrm{STN}, i}+\left(P_{\mathrm{STN}, i} \times \frac{P_{\mathrm{grad}}}{100} \times \Delta \mathrm{z}\right)\right),
$$

where $P_{\mathrm{STN}, i}$ is daily snowfall recorded the meteorological station $(\mathrm{mm}), P_{\text {grad }}$ is precipitation gradient $\left(\% \mathrm{~m}^{-1}\right)$ and $\Delta z$ is the elevation difference between the particular band ( $j$ ) and the meteorological station. The summation is over all days ( 1 to $m$ ) in winter (October to April). Here we use the mean $P_{\text {grad }}$ value derived from 12 glaciers (Table 1). The detailed methodology to calculate precipitation gradient is described in Tawde and others (2016).

The elevation at which the estimated snowmelt during the summer equals the winter snow accumulation at the end of the balance year is considered as the ELA. Based on the position of the ELA and the hypsometry of glaciers, the AAR is calculated. Further, the mass balance is calculated using the regression between AAR and mass balance. The regression relationship between model-derived AAR and fieldderived mass balance over Chhota Shigri Glacier obtained by Tawde and others (2016) is modified here since data are now available for a longer period. The station data are now available up to 2012 and were available only up to 2009 in our previous study. The modified regression $\left(r^{2}=0.84\right)$ using mass-balance estimates for the periods 1987-89 and 2002-12 is:

$$
B=186.3 \times \mathrm{AAR}-122.8
$$

where $B$ is the annual specific mass balance ( $\mathrm{cm}$ w.e.) of the glacier. As Chhota Shigri Glacier is found to represent the entire basin (Vincent and others, 2013; Pandey and others, 2016), the same regression is applied to all glaciers for the estimation of basin-wide mass balance.

The uncertainty in modelled mass balance is calculated considering two main components: uncertainty in (i) ELA and (ii) AAR. Uncertainty in modelled ELA is due to the independent uncertainties in temperature $\left( \pm 0.1^{\circ} \mathrm{C}\right)$, snowfall $( \pm 2 \%)$, temperature lapse rates $\left( \pm 0.5^{\circ} \mathrm{C} \mathrm{km}^{-1}\right)$, precipitation gradient $\left(50 \%\right.$ of the value, i.e. $\left.\pm 0.10 \% \mathrm{~m}^{-1}\right)$, snowmelt factor $\left( \pm 0.3 \mathrm{~mm}^{\circ} \mathrm{C}^{-1} \mathrm{~d}^{-1}\right)$ and DEM $( \pm 11 \mathrm{~m})$. One parameter at a time is changed, keeping others constant to calculate the uncertainty due to that parameter. Uncertainty in AAR estimate depends on independent uncertainties in modelderived ELA, glacier boundaries $( \pm 5 \%$, Pfeffer and others, 2014) and changes in glacier area over the study period $( \pm 2.5 \%$, Pandey and others, 2013a). Besides the uncertainty in the estimation of ELA and AAR, uncertainty in the modelled mass balance also depends on the uncertainty in glaciological observations used to derive the AAR/mass-balance regression $\left( \pm 0.4 \mathrm{~m}\right.$ w.e. $\mathrm{a}^{-1}$, Azam and others, 2012) and the usage of the same regression for other glaciers $( \pm 0.01 \mathrm{~m}$ w.e. $\mathrm{a}^{-1}$, Tawde and others, 2016). In the present analysis, uncertainty in mass balance is given by running the model for all years and glaciers in the basin.

\section{Volume estimation}

The volume of the basin is estimated using the slope-dependent method described by Haeberli and Hoelzle (1995). The reasons for preferring the slope-dependent method are the simplicity of the parameterisation scheme and the comparability of the results from this method with other ice-thickness 
distribution models over the western Himalaya (Frey and others, 2014). The geometric parameters needed for the slope-dependent method are calculated from the DEM (Frey and others, 2014). The average ice depth along the central flowline $\left(h_{\mathrm{t}}\right)$ in metres is estimated as

$$
h_{\mathrm{t}}=\frac{\tau}{f \rho g \sin (\alpha)}
$$

where $\tau$ is the mean basal shear stress along the central flowline, $f$ is the shape factor for valley glaciers $(0.8), \rho$ is ice density, $\alpha$ is slope and $g$ is the gravitational acceleration. The average thickness of glaciers $\left(h_{\mathrm{t}}\right)$ is estimated assuming semi-elliptical cross-section geometry. The volume is determined by multiplying $h_{\mathrm{t}}$ by the total surface area of the glacier. The uncertainty in volume is estimated using fractional uncertainty for Eqn (4) (Taylor, 1982). The uncertainties in $f, \rho$ and $\tau$ are taken as \pm 0.1 , $\pm 10 \%\left(90 \mathrm{~kg} \mathrm{~m}^{-3}\right.$ ) and $\pm 28 \mathrm{kPa}$ (SD considering all glaciers), respectively. The uncertainty in slope $\alpha$ is taken as the RMSE between DEM-derived-corrected slopes (Frey and others, 2014) and slope using $\arctan (\Delta H / I)$, where $\Delta H$ is the difference between the maximum and minimum elevation of the glacier and $/$ is the glacier length along the longest flowline. The basin-wide volume is represented in gigatonne w.e. (Gt w.e.).

\section{RESULTS}

\section{Mean ELA and mass balance}

As the climate data are available from 1984 to 2012, we assess the variations in ELA and mass balance of the basin for this 28-year period. ELA of the basin varies interannually from 4825 to $6425 \mathrm{~m}$ a.s.l., with a model uncertainty of $\pm 130 \mathrm{~m}$ (Fig. 2). The mean ELA of the basin is estimated at $5460 \pm 130 \mathrm{~m}$ a.s.I., with an SD of $\pm 420 \mathrm{~m}$. The trend in ELA suggests that it is increasing at a rate of $113 \mathrm{~m} \mathrm{decade}^{-1}$ (significant at $73 \%$ ) (Fig. 2). The mean AAR of the basin during 1984-2012 is calculated as $34 \pm 10 \%$.

Mean mass balance of the Chandra basin is expressed for individual glaciers, years and in terms of area-weighted value during 1984-2012. The area-weighted mean mass balance of the basin is $-0.61 \pm 0.46 \mathrm{~m}$ w.e. $\mathrm{a}^{-1}$. The mean mass balance of an individual glacier varies from $-1.22 \pm 0.46$ to $0.01 \pm 0.46 \mathrm{~m}$ w.e. $\mathrm{a}^{-1}$ (Fig. 3 ). The most negative mass balance is calculated for glaciers in the mean altitudinal range $4172-4746 \mathrm{~m}$ a.s.l., while the range is between 5565 and $5650 \mathrm{~m}$ a.s.I for glaciers with the least negative mass balance.

Interannual variations in area-weighted mass balance of the basin range from $-1.22 \pm 0.46$ to $+0.28 \pm 0.46 \mathrm{~m}$ w.e. $\mathrm{a}^{-1}$ (Fig. 4). A decreasing mass-balance trend of $0.11 \mathrm{~m}$ w.e. $\mathrm{a}^{-1}$ decade $^{-1}$ (significant at $75 \%$ ) is observed. The time-series analysis of glacier mass balance suggests a mass-balance rate of $-0.37 \pm 0.46 \mathrm{~m}$ w.e. $\mathrm{a}^{-1}$ during the first decade of the study period (1984-94). In the second decade (19942004), a mean mass balance of $-0.95 \pm 0.46 \mathrm{~m}$ w.e. $\mathrm{a}^{-1}$ is observed, indicating acceleration in mass loss. In the third period (2004-12), the mass loss continues at a rate of $-0.46 \pm 0.46 \mathrm{~m}$ w.e. $\mathrm{a}^{-1}$. However, for a few years, i.e. 1988-90, 1994, 2005 and 2009, we find basin-wide positive mass balance which is mostly associated with a positive anomaly in winter snowfall and a negative anomaly in summer temperatures (Fig. 4). After de-trending the data, we find correlation coefficients of +0.80 and -0.66 (at $99 \%$ confidence interval) between mass balance and winter snowfall and between mass balance and summer temperatures, respectively.

\section{Sensitivity of mass balance to climate variables}

We evaluate the sensitivity of mass balance for three cases: $\pm 1{ }^{\circ} \mathrm{C}$ change in temperature, \pm 10 and $\pm 20 \%$ change in precipitation. The sensitivity of mass balance to climate variables is calculated following Oerlemans and others (1998). For a $1{ }^{\circ} \mathrm{C}$ change in temperature, a change of $85 \mathrm{~m}$ in ELA is estimated. This translates to an area-weighted mean sensitivity of $0.16 \mathrm{~m}$ w.e. ${ }^{\circ} \mathrm{C}^{-1}$ in basin-wide mass balance. For individual glaciers, the sensitivity to temperature varies between 0.01 and $0.59 \mathrm{~m}$ w.e. ${ }^{\circ} \mathrm{C}^{-1}$ (Fig. 5). If precipitation is changed by 10 and $20 \%$, then ELA shifts by 47 and $114 \mathrm{~m}$, respectively. In terms of mass balance, a change of $0.09 \mathrm{~m}$ w.e. for a $10 \%$ change in precipitation is estimated, with a range of $0.01-0.33 \mathrm{~m}$ w.e. $(10 \%)^{-1}$. This indicates that a

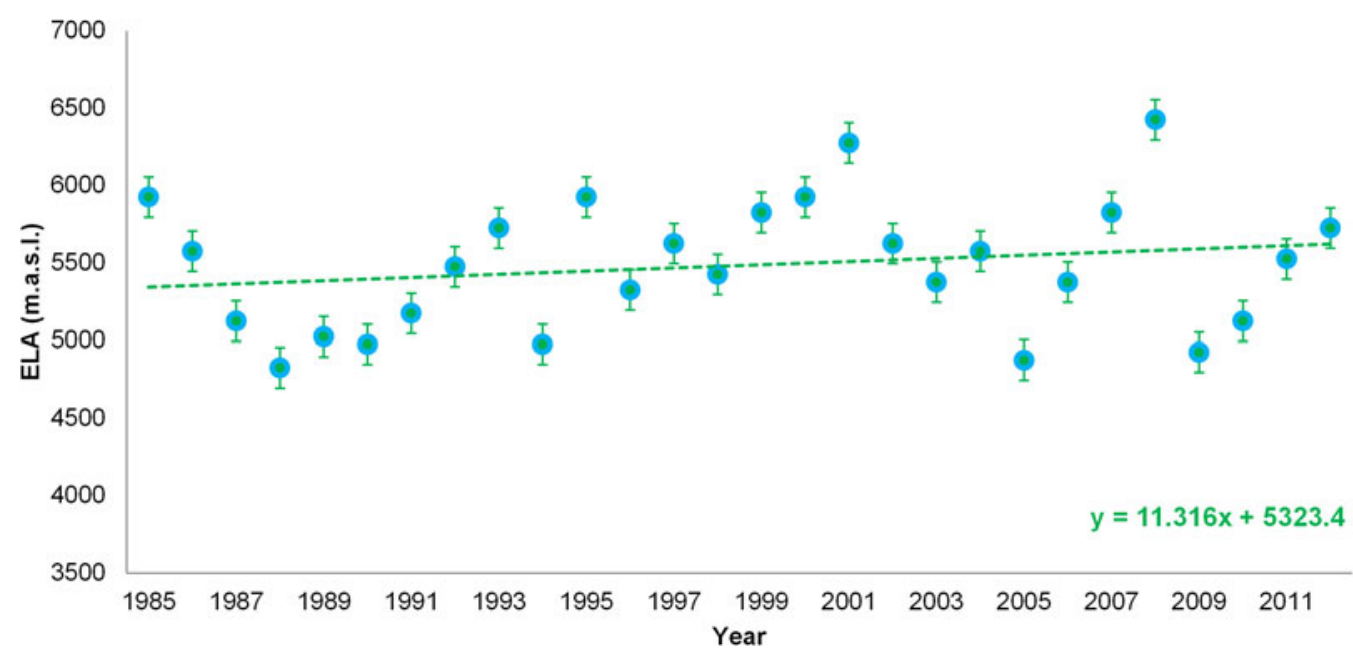

Fig. 2. Annual variations in modelled ELA of the Chandra basin from 1984 to 2012 . Filled circles represent annual mean ELA (m a.s.I.) averaged over all glaciers in the basin. The uncertainty in model-derived ELA is $\pm 130 \mathrm{~m}$. The dashed line indicates the trend in ELA, i.e. $+113 \mathrm{~m} \mathrm{decade}^{-1}$ (significant at $73 \%$ ). 


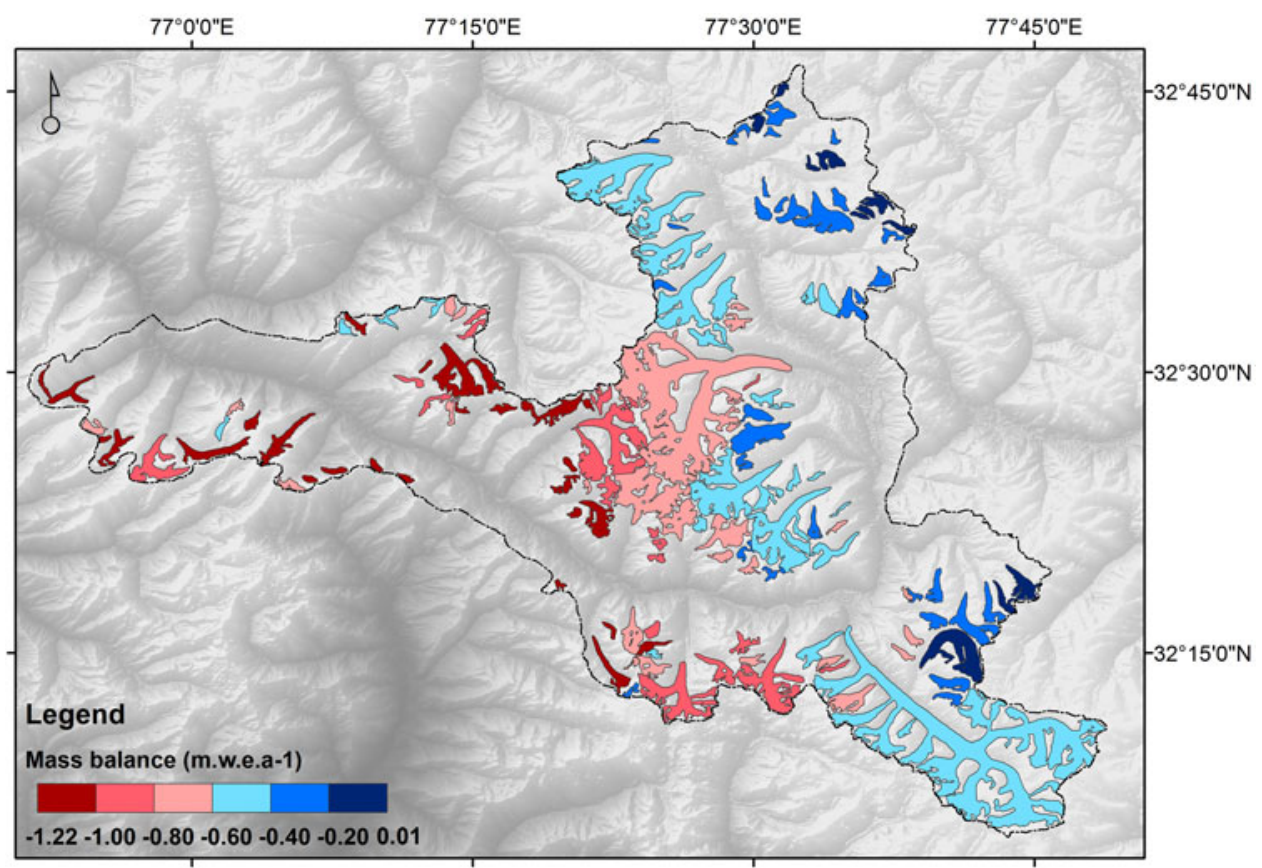

Fig. 3. Spatial distribution of modelled mean mass balance ( $m$ w.e. $\mathrm{a}^{-1}$ ) of glaciers in the Chandra basin from 1984 to 2012.

$+20 \%$ change in winter snowfall would offset the effect of a $+1{ }^{\circ} \mathrm{C}$ change in summer temperature of the basin.

We have estimated specific mass balance of individual glaciers, so the altitude-wise mass balance on each glacier is not available. Hence, the altitudinal variations in sensitivity at glacier scale could not be directly estimated. However, we have estimated the mass balance for 146 glaciers with mean altitude ranging from 4175 to $5650 \mathrm{~m}$ a.s.l. Therefore, to evaluate the influence of altitude on mass-balance sensitivity, we can use the mean altitude of individual glaciers (Fig. 5). Here we analyse mass-balance sensitivity to temperature, as this is the most commonly discussed quantity in the context of climate change. Sensitivity of mass balance is found to be at a maximum when the mean altitude of the glacier is near the ELA (Fig. 5). This may be because the model-derived mass balance depends on the glacier hypsometry. Therefore, we have grouped glaciers into three categories: top heavy, equidimensional and bottom heavy. The hypsometry index defined by Jiskoot and others (2009) is used to classify glaciers based on the area-altitude distributions. We find that $16 \%$ of the total glaciers are in the top heavy' category and they have the highest mass-balance sensitivity of $0.20 \mathrm{~m}$ w.e. ${ }^{\circ} \mathrm{C}^{-1}$. Nearly $34 \%$ of the glaciers in the 'equidimensional' and $50 \%$ in the 'bottom heavy' category have mass-balance sensitivities of 0.17 and $0.15 \mathrm{~m}$ w.e. ${ }^{\circ} \mathrm{C}^{-1}$, respectively. The category-wise sensitivity suggests that the 'bottom heavy' glaciers are least sensitive, which is in agreement with the results of Jiskoot and others (2009).

\section{Volume of the basin}

To analyse the proportion of mass loss in the total glacierstored water, we investigate the glacier volume of the basin. The total surface area of the selected glaciers is $654.29 \mathrm{~km}^{2}$. The total ice volume estimated for these glaciers is $62.10 \pm 16 \mathrm{Gt}$ w.e. The ice thickness along the central flowline $\left(h_{\mathrm{f}}\right)$ of glaciers ranges between $17 \pm 4$ and $268 \pm$ $56 \mathrm{~m}$. The volume of individual glaciers in the basin varies between $0.06 \pm 0.02$ and $21.32 \pm 6 \mathrm{Gt}$ w.e. (Fig. 6). The uncertainty in the volume is calculated as $\pm 26 \%$. The highest volume is estimated for Bara Shigri Glacier, and only $8 \%$ of the total number of glaciers have a volume of $>1$ Gt w.e. Hypsometric information on the volume indicates that nearly $99 \%$ of the total water volume in the basin is located at mean glacier elevations of 4600-5600 m a.s.I (Fig. 7).

\section{Cumulative volume loss}

Cumulative mass loss of the basin indicates acceleration from the 1990s and especially after 1995 (Fig. 8). In total, the Chandra basin has experienced a water loss of $11.1 \pm 8 \mathrm{Gt}$ from 1984 to 2012, which is approximately one-fifth of the total estimated volume. Out of this, the basin has lost 1.17 \pm 2 Gt w.e. in the 1980 s, $5.03 \pm 3$ Gt w.e. in 1990s and $4.20 \pm 3$ Gt w.e. in the 2000s. This sharp reduction in glacier mass from the 1990s can partially be explained by temperature rises of +4 and $+2{ }^{\circ} \mathrm{C}$ in the 1990s and 2000s, respectively, compared with temperatures in the 1980s.

Hypsometry of volume suggests that $94.5 \%$ of the total volume of the glaciers is below the mean ELA of the basin (ELA0 in Fig. 7). Between 1985-95 and 1995-2005, the mean summer temperature and winter snowfall of the basin have changed approximately by $+2{ }^{\circ} \mathrm{C}$ and $-20 \%$, respectively. This is equivalent to a rise in ELA by $300 \mathrm{~m}$ and a $44 \%$ decrease in the ice volume stored above the ELA of the glaciers (Fig. 7).

\section{DISCUSSION}

\section{Comparison of mass-balance estimates}

In Chandra-Bhaga and surrounding basins, numerous investigations have been carried out to estimate ELA (Kulkarni and others, 2004; Pandey and others, 2013b, 2016; Guo and others, 2014). These investigations are based on field- or satellite-derived snowlines at the end of summer (Kulkarni and 


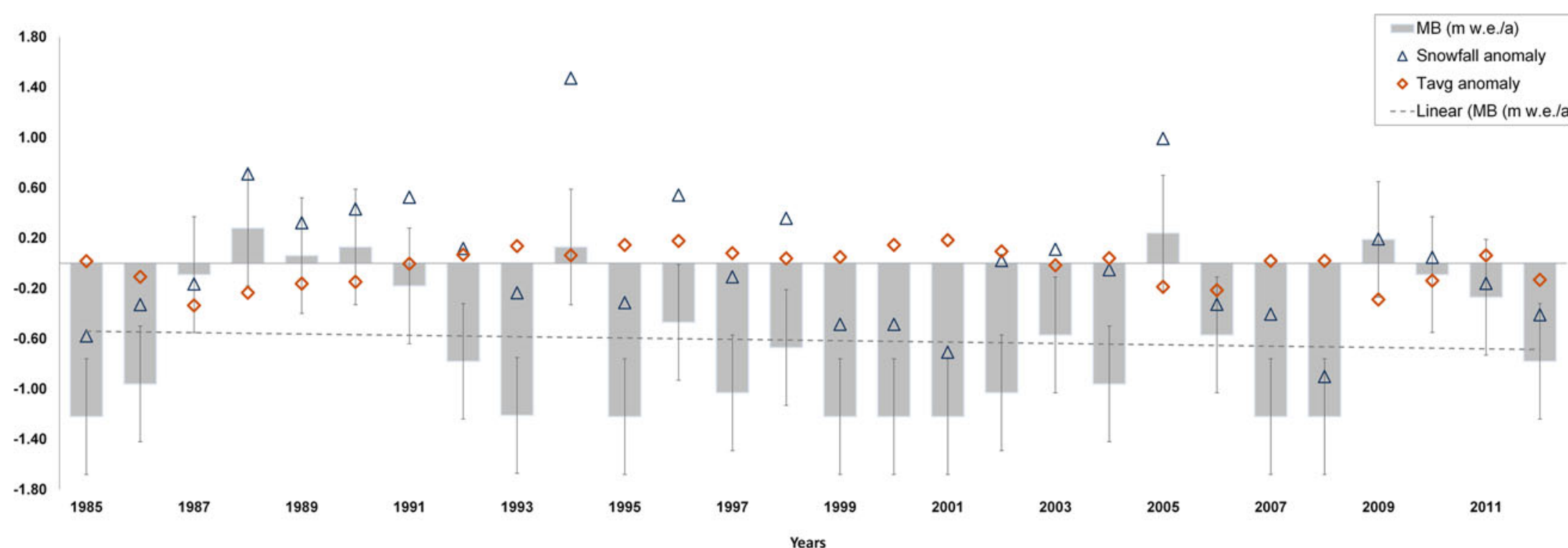



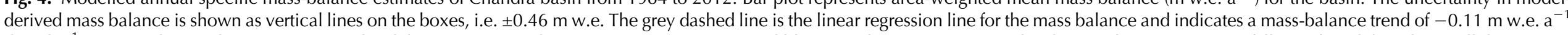

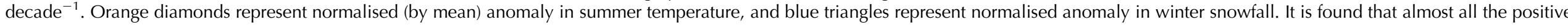
mass-balance years are accompanied by positive anomaly in snowfall and negative anomaly in temperature. 




Fig. 5. Sensitivity of mass balance to temperature change versus mean elevation of individual glacier in the basin. The red line indicates the mean ELA of the basin from 1984 to 2012.

others, 2004; Pandey and others, 2013b; Guo and others, 2014; Azam and others, 2016). In addition, these investigations are available for different time frames, i.e. 19802009. Thus, we find a large variation in ELA (Table 2). For example, in Chandra-Bhaga basin, the mean ELA is estimated at $5009 \pm 61$ to $5401 \pm 21 \mathrm{~m}$ a.s.l. for the period 1980-2007 (Pandey and others, 2013b). For the adjacent Baspa basin, the ELA varies between 4960 and $5560 \mathrm{~m}$ a.s.l. for the years 2000-02 (Kulkarni and others, 2004), and for the western Himalaya, it varies between 4840 and $5770 \mathrm{~m}$ a.s.l. during 1998-2009 (Guo and others, 2014). This is comparable with our mean ELA estimate of $5460 \pm 130 \mathrm{~m}$ a.s.l. for the period 1984-2012. Though the model-derived ELA of the basin is comparable with snowline altitudes at a larger spatial scale, it is higher than the field-derived ELA of Chhota Shigri Glacier, i.e. 5056 m a.s.l. (Azam and others,
2016). This is likely due to the different orientations of glaciers (Kulkarni and others, 2004; Guo and others, 2014) and the presence of several small glaciers in the basin. Model-derived mean AAR $(0.34 \pm 0.1)$ is also consistent with the satellite-derived AAR of 0.44 between 1980 and 2014 for the same basin (Pandey and others, 2016).

In order to validate modelled mass balance at basin scale, we compare it with the geodetic method. The geodetic massbalance estimates covering the basin are available from 1999 to 2012 (Gardelle and others, 2013; Vincent and others, 2013; Vijay and Braun, 2016). The original investigations were carried out for the entire Lahual-Spiti region in the western Himalaya. Therefore, we have extracted the Chandra basin from the published elevation change data by Gardelle and others (2013) and Vijay and Braun (2016). The geodetic mass balance for the basin is $-0.68 \pm 0.15$

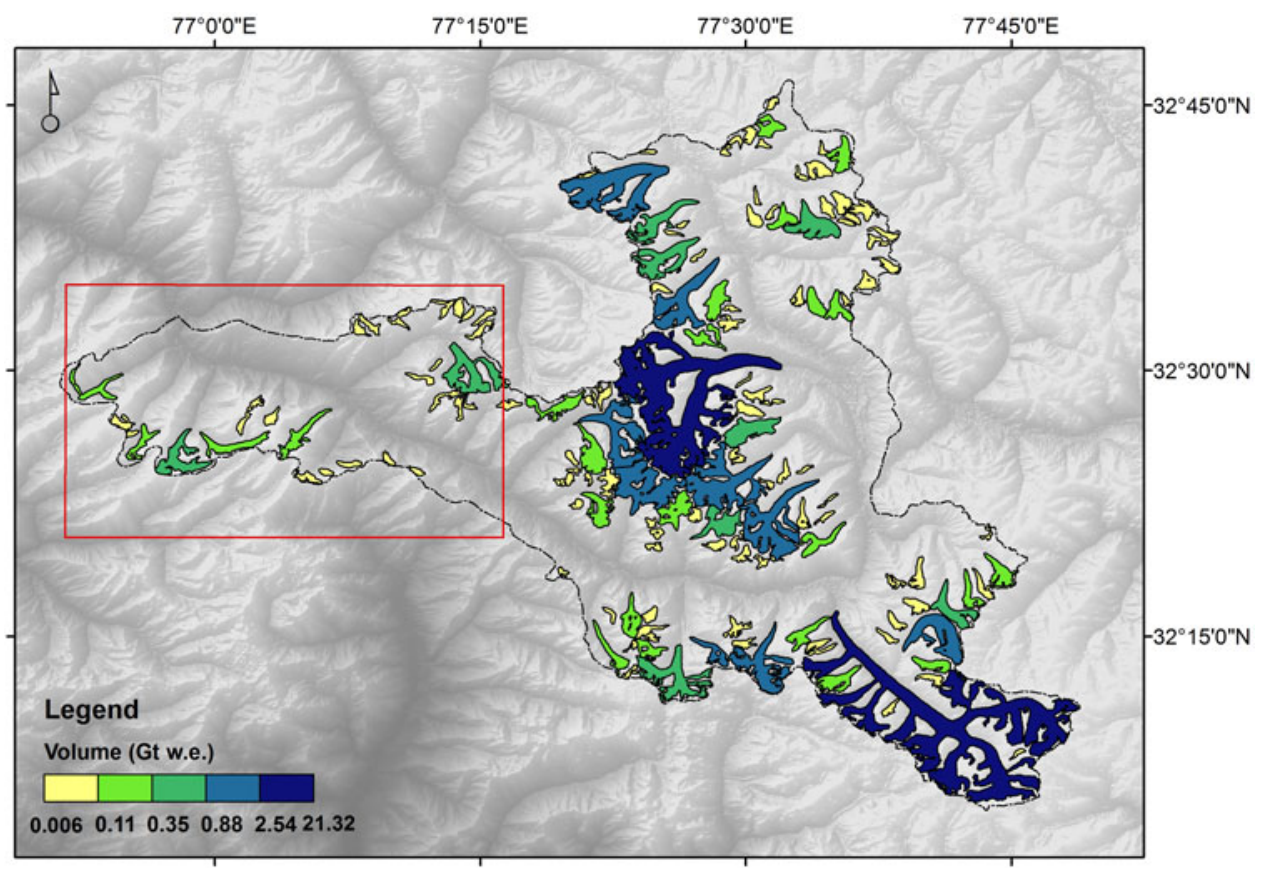

Fig. 6. Spatial distribution of water stored in individual glaciers of the Chandra basin. The highest volume is estimated for Bara Shigri $(21.32 \pm$ 6 Gt w.e.) and Samudra Tapu Glacier (12.33 \pm 3 Gt w.e.). The box represents selected glaciers in low-altitude regions of the basin, where $67 \%$ of loss in glacier-stored water is estimated. 


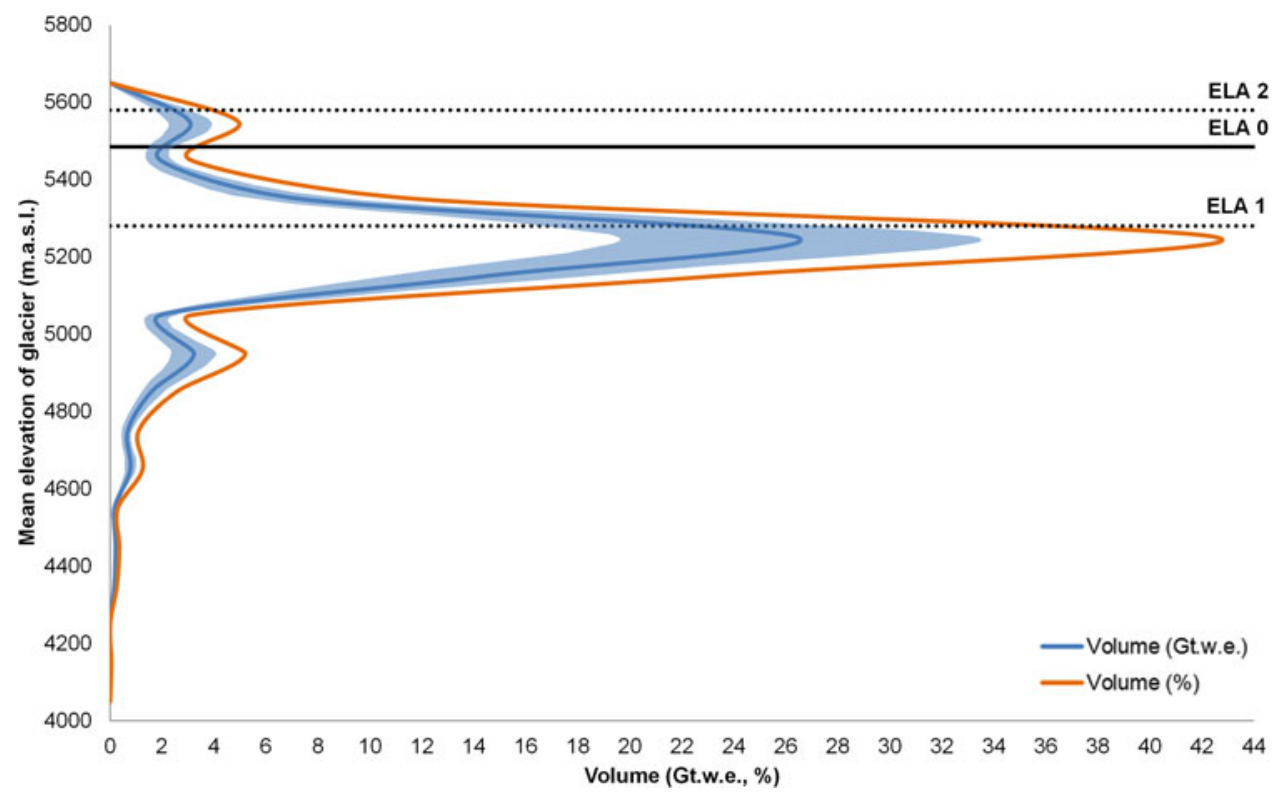

Fig. 7. Hypsometric distribution of volume with respect to the mean glacier elevation in the Chandra basin. Blue line represents volume in Gt w.e., with shaded area as uncertainty. Orange line represents fractional (\%) volume stored at each elevation band. ELA0 is the mean ELA of the basin from 1984 to 2012. ELA1 and ELA2 are the mean ELAs of the decades 1985-95 and 1995-2005, respectively.

and $-0.65 \pm 0.04 \mathrm{~m}$ w.e. $\mathrm{a}^{-1}$ for the periods $1999-2011$ and 2000-12, respectively (Table 2 ). Our mass-balance estimates are $-0.66 \pm 0.46 \mathrm{~m}$ w.e. $\mathrm{a}^{-1}$ for $1999-2011$ and $-0.63 \pm$ $0.46 \mathrm{~m}$ w.e. $\mathrm{a}^{-1}$ for 2000-12. Kääb and others (2012) estimate elevation changes in a $2^{\circ} \times 2^{\circ}$ cell around Chhota Shigri Glacier using the Ice, Cloud and land Elevation Satellite (ICESat) data and estimate a mass balance of $-0.66 \pm 0.07 \mathrm{~m}$ w.e. $\mathrm{a}^{-1}$ for 2003-08. The Chandra basin occupies $5 \%$ of the total area covered in Kääb and others (2012), and our mass estimate for the same period is $-0.74 \pm 0.46 \mathrm{~m}$ w.e. $\mathrm{a}^{-1}$.

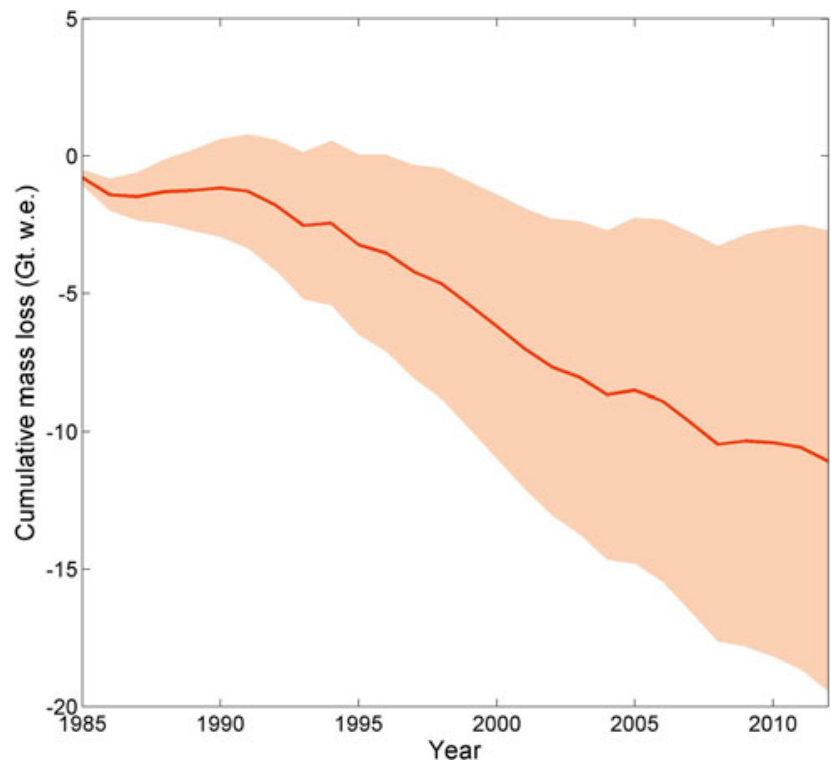

Fig. 8. Cumulative mass balance of the Chandra basin from 1984 to 2012 in Gt w.e. Uncertainty in the model-derived mass balance is shown by the shaded area. Mass loss of the basin is found to have accelerated from the 1990s, especially after 1995. It is found that the basin has lost $11.1 \pm 8 \mathrm{Gt}$ of water out of $62.10 \pm 16 \mathrm{Gt}$ of the total estimated water volume.
Mass-balance estimates in earlier studies on global, regional and individual glacier scales overlapping the same period have shown wide variation (Vincent, 2002; Zemp and others, 2008; Braithwaite, 2009; Cogley, 2009; Fujita and Nuimura, 2011; Bolch and others, 2012; Huss, 2012; Azam and others, 2014a). Mass-balance estimates on a global scale are available for the period 1860-2010, and show a sudden drop in glacier mass balance in the 1990s compared with the previous decades (Dyurgerov and Meier, 2000; Zemp and others, 2008; Braithwaite, 2009; Cogley, 2009). For example, Zemp and others (2008) found

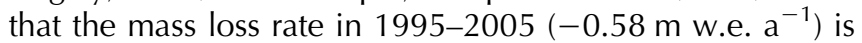
twice that in 1985-95 $\left(-0.25 \mathrm{~m}\right.$ w.e. $\left.\mathrm{a}^{-1}\right)$. Similar results are also observed at regional scales in the European Alps (Vincent, 2002; Huss, 2012) as well as over the Himalaya (Fujita and Nuimura, 2011; Bolch and others, 2012). The value reported for the Alps in the $1980 \mathrm{~s}$ is $-0.40 \mathrm{~m}$ w.e. $\mathrm{a}^{-1}$ and is $-0.84 \mathrm{~m} \mathrm{w.e.} \mathrm{a}^{-1}$ for $1990-2010$ (Huss, 2012). Our modelled mass-balance rate for the basin is in close agreement with the analysis of aforementioned studies (Table 2). The warming after 1990 in the Himalayan regions could partly explain the increase in model-derived mass loss (Bhutiyani and others, 2010; Banerjee and Azam, 2016).

Our results also partly agree with the model estimates for Chhota Shigri Glacier, where a change in mass balance is observed after 1999. The reported mass balance for the glacier is between -0.018 and $+0.09 \mathrm{~m}$ w.e. $\mathrm{a}^{-1}$ during 1988-99 (Vincent and others, 2013; Azam and others, 2014a) and $-0.56 \mathrm{~m}$ w.e. $\mathrm{a}^{-1}$ after 1999 (Azam and others, 2014a). Our estimates suggest a basin-wide mass loss of $-0.57 \pm 0.46$ and $-0.69 \pm 0.46 \mathrm{~m}$ w.e. $\mathrm{a}^{-1}$ in 1988-99 and 1999-2010, respectively. Our basin-wide results differ from those obtained over Chhota Shigri Glacier for the period 1988-99 because, though the AAR/ mass-balance relation is based on field measurements at Chhota Shigri Glacier, the basin-wide modelled massbalance estimates are also influenced by area-altitude distributions, which vary from glacier to glacier. 
Table 2. Comparison of model-derived ELA ( $\mathrm{m}$ a.s.l.) and AAR and mass-balance ( $\mathrm{m}$ w.e. $\mathrm{a}^{-1}$ ) estimates with other studies at basin or larger spatial scales

ELA

\begin{tabular}{|c|c|c|c|c|c|}
\hline Region & Period & Model estimates & Other study & Method used & Source \\
\hline Chandra Bhaga basin & 1980-2007 & $5482 \pm 130^{*}$ & $5009 \pm 61$ to $5401 \pm 21$ & Manual delineation & Pandey and others (2013b) \\
\hline Baspa & 2000-2002 & $5950 \pm 130$ & 4960 to 5560 & Manual delineation & Kulkarni and others (2004) \\
\hline Lahaul-Spiti & 2002 & $5925 \pm 130$ & $5390 \pm 140$ & Manual delineation & Gardelle and others (2013) \\
\hline Western Himalaya & 1998-2009 & $5620 \pm 130$ & 4840 to 5770 & Manual delineation & Guo and others (2014) \\
\hline \multicolumn{6}{|l|}{ AAR } \\
\hline Region & Period & Model estimates & Other study & Method used & Source \\
\hline Chandra basin & 1980-2014 & $0.34 \pm 0.1^{*}$ & 0.44 & Manual delineation & Pandey and others (2016) \\
\hline \multicolumn{3}{|l|}{ Mass balance } & Other study & Method used & Source \\
\hline Chandra basin & 1999-2011 & $-0.66 \pm 0.46$ & $-0.68 \pm 0.15$ & Geodetic $^{\neq}$ & Gardelle and others (2013) \\
\hline Chandra basin & 2000-2012 & $-0.63 \pm 0.46$ & $-0.65 \pm 0.04$ & Geodetic $^{\neq}$ & Vijay and Braun (2016) \\
\hline $\begin{array}{l}2^{\circ} \times 2^{\circ} \text { around Chhota } \\
\text { Shigri Glacier }\end{array}$ & 2003-2008 & $-0.74 \pm 0.46$ & $-0.66 \pm 0.07$ & Geodetic $^{\ddagger}$ & Kääb and others (2012) \\
\hline Baspa basin (19 glaciers) & 2000-2002 & $-1.13 \pm 0.46$ & -0.84 & AAR & Kulkarni and others (2004) \\
\hline Lahaul-Spiti & 1999-2004 & $-1.00 \pm 0.46$ & $-0.65 \pm 0.17$ & Geodetic & Vincent and others (2013) \\
\hline \multirow{2}{*}{$\begin{array}{l}\text { European glacier Alps } \\
\text { (50 glaciers) }\end{array}$} & 1980-1990 & $-0.30 \pm 0.46^{*}$ & -0.40 & Glaciological + models & Huss (2012) \\
\hline & 1990-2010 & $-0.71 \pm 0.46$ & -0.84 & Glaciological + models & Huss (2012) \\
\hline \multirow{2}{*}{ Global (30 glaciers) } & 1985-1995 & $-0.37 \pm 0.46$ & -0.25 & Glaciological & Zemp and others (2008) \\
\hline & 1995-2005 & $-0.81 \pm 0.46$ & -0.58 & Glaciological & Zemp and others (2008) \\
\hline
\end{tabular}

* The present study covers the period 1984/85 to 2011/12 (here referred as 1984-2012).

+ Modelled mass balance is restricted to the Chandra basin.

₹ The height change is converted to mass change using ice density of $850 \mathrm{~kg} \mathrm{~m}^{-3}$.

\section{Comparison of sensitivity estimates}

ELA and mass-balance sensitivity to climate variables at regional scale have been carried out in different parts of the globe, i.e. the Canadian Rockies, Swiss Alps, French Alps, Australian Alps, Norway, Arctic and Himalaya (Oerlemans and Fortuin, 1992; Braithwaite and Zhang, 1999; Braithwaite and others, 2002; Vincent, 2002; Oerlemans and others, 2005; Woul and Hock, 2005; Zemp and others, 2007; Rabatel and others, 2013; Rasmussen, 2013; Thibert and others, 2013; Six and Vincent, 2014; Shea and Immerzeel, 2016). ELA sensitivity reported in the European Alps varies between 50 and $115 \mathrm{~m}^{\circ} \mathrm{C}^{-1}$ (Kuhn, 1989; Vincent, 2002; Zemp and others, 2007; Rabatel and others, 2013; Thibert and others, 2013; Six and Vincent, 2014). For Beas basin in the Himalaya, the estimated ELA response to temperature change is large $\left(164 \mathrm{~m}^{\circ} \mathrm{C}^{-1}\right.$, Shea and Immerzeel, 2016). However, this larger sensitivity for Beas basin is estimated by considering annual precipitation (of $1740 \mathrm{~mm}$ ). According to the function derived by Shea and Immerzeel (2016), the Chandra basin has a sensitivity of $\sim 73 \mathrm{~m}^{\circ} \mathrm{C}^{-1}$ for the annual precipitation of $\sim 461 \mathrm{~mm}$ at the lowest glacier altitude. Our modelled estimate of ELA sensitivity for the basin $\left(85 \mathrm{~m}^{\circ}\right.$ $\mathrm{C}^{-1}$ ) agrees closely with this value.

The mass-balance sensitivity is reported in a range of 0.1-1.3 m w.e. ${ }^{\circ} \mathrm{C}^{-1}$ when glaciers around the world are considered (Oerlemans and Fortuin, 1992; Braithwaite and Zhang, 1999; Braithwaite and others, 2002). It varies from 0.2 to $2.0 \mathrm{~m}^{\circ} \mathrm{C}^{-1}$ for Arctic glaciers (Woul and Hock, 2005) and between 0.2 and $0.5 \mathrm{~m}$ w.e. ${ }^{\circ} \mathrm{C}^{-1}$ for glaciers in high Asia (Rasmussen, 2013). The observed sensitivity to precipitation is in the range $0.03-0.36 \mathrm{~m}(10 \%)^{-1}$ for Arctic glaciers (Woul and Hock, 2005). The sensitivity reported at glacier scale in the Himalaya is higher, varying from 0.47 to $0.52 \mathrm{~m}$ w.e. ${ }^{\circ} \mathrm{C}^{-1}$ for temperature and from 0.14 to 0.16 $\mathrm{m}$ w.e. $(10 \%)^{-1}$ (Mölg and others, 2012; Azam and others, 2014a) for precipitation. Our area-weighted mean sensitivity of the basin is $0.16 \mathrm{~m}$ w.e. ${ }^{\circ} \mathrm{C}^{-1}$ for temperature and $0.09 \mathrm{~m}$ w.e. $(10 \%)^{-1}$ for precipitation.

From the above discussion, we find that our modelled ELA sensitivity is in agreement with available literature on glacier and regional scales but the mass-balance sensitivity is in agreement only at regional scale. This may be because the model-derived mass balance is controlled by the position of the ELA as well as the area-altitude distribution of individual glaciers. Therefore, for a change in ELA, the response in terms of mass balance will be divergent depending on the area above/below the ELA. This is further discussed in the Results subsection above on sensitivity of mass balance to climate variables.

\section{CONCLUSION}

We have analysed annual mass-balance estimates at basin scale using a simple model and limited inputs, in order to fill the gap in mass-balance series over the Himalaya. The present study is a sequel to Tawde and others (2016), where the improved AAR method to estimate mass balance was described using satellite-derived snowlines and the TI model. The method calculates the position of the ELA using temperature and precipitation data. Then the mass balance is derived using AAR/mass-balance regression developed for the basin. The performance of the present approach is dependent on two main quantities: reliable climate data and $\mathrm{AAR} /$ mass-balance regression. A detailed discussion on uncertainty in the present approach is provided in Tawde and others (2016). 
In the present study, for the first time, we estimate annual mass balance of glaciers in the Chandra basin for almost three decades. We have modelled the annual specific mass balance of 146 glaciers in the basin from 1984 to 2012 . Our model results yield a mean ELA of the basin of $5460 \pm$ $130 \mathrm{~m}$ a.s.l. The area-weighted mean mass balance is estimated at $-0.61 \pm 0.46 \mathrm{~m}$ w.e. $\mathrm{a}^{-1}$, which is equivalent to $11.1 \pm 8 \mathrm{Gt}$ of water loss from the basin in 28 years. The results of the sensitivity analysis show that a $20 \%$ increase in winter precipitation can balance the basin-wide massbalance changes for a $1{ }^{\circ} \mathrm{C}$ rise in summer temperature. According to our estimates, the total water volume of the basin is $62.1 \pm 16 \mathrm{Gt}$, which is equivalent to $0.18 \mathrm{~mm}$ of mean sea-level rise. Approximately $94 \%$ of this is calculated to be in the ablation zone of glaciers. This suggests that future glacier wastage would continue even in the absence of global warming.

Even though, on a basin scale, only $18 \%$ of the total glacier-stored water has been lost during 1984-2012, the loss could be large for many small and low-altitude glaciers (Fig. 6). For example, 29 glaciers located in the lower altitudinal range have lost $67 \%$ of water. This substantial loss suggests that small villages located in this valley may experience water scarcity.

\section{SUPPLEMENTARY MATERIAL}

The supplementary material for this article can be found at https://doi.org/10.1017/aog.2017.18.

\section{ACKNOWLEDGEMENT}

We are grateful to the Divecha Centre for Climate Change and Centre for Atmospheric and Oceanic Sciences at the Indian Institute of Science, Bangalore, India, for providing laboratory facilities. We also thank the US Geological Survey for making ASTER GDEM data available. ASTER GDEM is a product of METI and NASA. We acknowledge Etienne Berthier and Saurabh Vijay for providing geodetic estimates for the Chandra basin. We also thank the Bhakra Beas Management Board (BBMB) for meteorological data of Kaza station. Reviews by F. Azam and an anonymous reviewer helped to improve an earlier version of the manuscript.

\section{REFERENCES}

Azam MF and 10 others (2012) From balance to imbalance: a shift in the dynamic behaviour of Chhota Shigri Glacier, western Himalaya, India. J. Glaciol., 58(208), 315-324 (doi: 10.3189/ 2012JoG11J123)

Azam MF and 5 others (2014a) Reconstruction of the annual mass balance of Chhota Shigri Glacier, Western Himalaya, India, since 1969. Ann. Glaciol., 55(66), 69-80 (doi: 10.3189/ 2014AoG66A104)

Azam MF and 6 others (2014b) Processes governing the mass balance of Chhota Shigri Glacier (western Himalaya, India) assessed by point-scale surface energy balance measurements. Cryosphere, 8, 2195-2217 (doi: 10.5194/tc-8-2195-2014)

Azam MF and 10 others (2016) Meteorological conditions, seasonal and annual mass balances of Chhota Shigri Glacier, western Himalaya, India. Ann. Glaciol., 57(71), 328-338 (doi: 10.3189/ 2016AoG71A570)

Banerjee A and Azam MF (2016) Temperature reconstruction from glacier length fluctuations in the Himalaya. Ann. Glaciol., 57 (71), 189-198 (doi: 10.3189/2016AoG71A047)
Barnett TP, Adam JC and Lettenmaier DP (2005) Potential impacts of a warming climate on water availability in snow-dominated regions. Nature, 438, 303-309 (doi: 10.1038/nature04141)

Berthier E and 5 others (2007) Remote sensing estimates of glacier mass balances in the Himachal Pradesh (Western Himalaya, India). Remote Sens. Environ., 108(3), 327-338 (doi: 10.1016/j. rse.2006.11.017)

Bhutiyani MR, Kale VS and Pawar NJ (2010) Climate change and the precipitation variations in the northwestern Himalaya: 1866-2006. Int. J. Climatol., 30(4), 535-548

Blard PH and 5 others (2011) Degree-day melt models for paleoclimate reconstruction from tropical glaciers: calibration from mass balance and meteorological data of the Zongo glacier (Bolivia, 16 S). Clim. Past Discuss., 7(3), 2119-2158 (doi: 10.5194/cpd-7-2119-2011)

Bolch T and 11 others (2012) The state and fate of Himalayan Glaciers Science, 336(6079), 310-314 (doi: 10.1126/science.1215828)

Brahmbhatt RM and 5 others (2011) Variation of snowline and mass balance of Glaciers of Warwan and Bhut basins of Western Himalaya using Remote Sensing Technique. J. Indian Soc. Remote Sens., 40(4), 629-637

Braithwaite RJ (2009) After six decades of monitoring glacier mass balance we still need data but it should be richer data. Ann. Glaciol., 50(50), 191-197 (doi: 10.3189/172756409787769573)

Braithwaite RJ and Zhang Y (1999) Modelling changes in glacier mass balance that may occur as a result of climate changes. Geogr. Ann., 81A(4), 489-496

Braithwaite RJ, Zhang Y and Raper SCB (2002) Temperature sensitivity of the mass balance of mountain glaciers and ice caps as a climatological characteristic. Z. Gletscherkd. Glazialgeol., 38(1), 35-61

Carenzo M (2012) Distributed modelling of changes in glacier mass balance and runoff (PhD thesis, ETH Zürich)

Chaturvedi RK, Kulkarni A, Karyakarte Y, Joshi J and Bala G (2014) Glacial mass balance changes in the Karakoram and Himalaya based on CMIP5 multi-model climate projections. Clim. Change, 123(2), 315-328 (doi: 10.1007/s10584-0131052-5)

Cogley JG (2009) Geodetic and direct mass-balance measurements: comparison and joint analysis. Ann. Glaciol., 50(50), 96-100 (doi: 10.3189/172756409787769744)

Dyurgerov MB and Meier MF (2000) Twentieth century climate change: evidence from small glaciers. PNAS, 97(4), 1406-1411

Favier $\mathrm{V}$ and 5 others (2011) Modeling the mass and surface heat budgets in a coastal blue ice area of Adelie Land, Antarctica. J. Geophys. Res., 116, F03017 (doi: 10.1029/2010JF001939).

Frey $\mathrm{H}$ and 9 others (2014) Estimating the volume of glaciers in the Himalayan-Karakoram region using different methods. Cryosphere, 8, 2313-2333 (doi: 10.5194/tc-8-2313-2014)

Fujita K and Nuimura T (2011) Spatially heterogeneous wastage of Himalayan glaciers. PNAS, 108(34), 14011-14014 (doi: 10.1073/pnas.1106242108)

Gabbi J, Carenzo M, Pellicciotti F, Bauder A and Funk M (2014) A comparison of empirical and physically based glacier surface melt models for long-term simulations of glacier response. J. Glaciol., 60(224), 1140-1154 (doi: 10.3189/2014JoG14J011)

Gardelle J, Berthier E, Arnaud Y and Kääb A (2013) Region-wide glacier mass balances over the Pamir-Karakoram-Himalaya during 1999-2011. Cryosphere, 7(4), 1263-1286 (doi: 10.5194/tc-7-1263-2013)

Guo Z and 6 others (2014) Temporal and spatial changes in Western Himalayan firn line altitude from 1998 to 2009. Glob. Planet. Change, 118, 97-105

Haeberli W and Hoelzle M (1995) Application of inventory data for estimating characteristics of and regional climate-change effects on mountain glaciers: a pilot study with the European Alps. Ann. Glaciol., 21, 206-212

Hock R (1999) A distributed temperature-index ice- and snowmelt model including potential direct solar radiation. J. Glaciol., 45 (149), 101-111 
Huss M (2012) Extrapolating glacier mass balance to the mountainrange scale: the European Alps 1900-2100. Cryosphere, 6, 713-727 (doi: 10.5194/tc-6-713-2012)

Huss M, Farinotti D, Bauder A and Funk M (2008) Modelling runoff from highly glacierized alpine drainage basins in a changing climate. Hydrol. Process., 22, 3888-3902

Immerzeel WW, van Beek LPH, Konz $M$, Shrestha $A B$ and Bierkens MFP (2012) Hydrological response to climate change in a glacierized catchment in the Himalayas. Clim. Change, 110, 721-736 (doi: 10.1007/s10584-011-0143-4)

Jiskoot H, Curran CJ, Tessler DL and Shenton LR (2009) Changes in Clemenceau Icefield and Chaba Group glaciers, Canada, related to hypsometry, tributary detachment, length-slope and areaaspect relations. Ann. Glaciol., 50(53), 133-143

Kääb A, Berthier E, Nuth C, Gardelle J and Arnaud Y (2012) Contrasting patterns of early 21 st century glacier mass change in the Himalaya. Nature, 488(7412), 495-498 (doi: 10.1038/nature11324)

Kuhn M (1989) The response of the equilibrium line altitude to climatic fluctuations: theory and observations. In Oerlemans J ed. Glacier fluctuations and climatic change. Kluwer Academic Publishers, Dordrecht, 407-417

Kulkarni AV (1996) Effect of climatic variations on Himalayan glaciers: a case study of upper Chandra River basin, Himachal Pradesh. In Proceedings of the Indo-US symosium-workshop on remote sensing and its application, 6 Oct.-9 Oct. 1996, Mumbai, India.

Kulkarni AV, Rathore BP and Alex S (2004) Monitoring of glacial mass balance in the Baspa basin using accumulation area ratio method. Curr. Sci., 86(1), 185-190

Lutz AF, Immerzeel WW, Shrestha AB and Bierkens MFP (2014) Consistent increase in High Asia's runoff due to increased glacier melt and precipitation. Nat. Clim. Change, 4, 587-592 (doi: 10.1038/NCLIMATE2237)

Matsuo K and Heki K (2010) Time-variable ice loss in Asia high mountains from satellite gravimetry. Earth Planet. Sci. Lett., 290 (1), 30-36

Mir RA, Jain SK, Arun KS and Goswami A (2014) Detection of changes in glacier mass balance using satellite and meteorological data in Tirungkhad basin located in Western Himalaya. J. Indian Soc. Remote Sens., 42(1), 91-105 (doi: 10.1007/s12524-013-0303-2)

Mölg T, Maussion F, Yang W and Scherer D (2012) The footprint of Asian monsoon dynamics in the mass and energy balance of a Tibetan glacier. Cryosphere, 6, 1445-1461 (doi: 10.5194/tc-61445-2012)

Oerlemans J and Fortuin JPF (1992) Sensitivity of glaciers and small ice caps to greenhouse warming. Science, 258(5079), 115-117

Oerlemans J and 10 others (1998) Modelling the response of glaciers to climate warming. Clim. Dyn., 14(4), 267-274 (doi: 10.1007/ s003820050222)

Oerlemans J and 8 others (2005) Estimating the contribution from Arctic glaciers to sea-level change in the next 100 years. Ann. Glaciol., 42(1), 230-236 (doi: 10.3189/172756405781812745)

Pandey P and Venkataraman G (2013a) Changes in the glaciers of Chandra-Bhaga basin, Himachal Himalaya, India, between 1980 and 2010 measured using remote sensing. Int. J. Remote Sens., 34(15), 5584-5597 (doi: 10.1080/01431161.2013.793464)

Pandey P, Kulkarni AV and Venkataraman G (2013b) Remote sensing study of snowline altitude at the end of melting season, Chandra-Bhaga basin, Himachal Pradesh, 1980-2007. Geocarto Int., 28(4), 311-322 (doi: 10.1080/10106049.2012. 705336)

Pandey P, Ali SN, Ramanathan AL, Champati ray PK and Venkataraman G (2016) Regional representation of glaciers in Chandra Basin region, western Himalaya, India. Geosci. Front., 8(4), 841-850 (doi: 10.1016/j.gsf.2016.06.006)
Paterson WSB (2000) Physics of glaciers. $3^{\text {rd }}$ edn. ButterworthHeinemann, Oxford.

Pellicciotti $F$ and 5 others (2005) An enhanced temperatureindex glacier melt model including the shortwave radiation balance: development and testing for Haut Glacier d' Arolla, Switzerland. J. Glaciol., 51(175), 573-587

Pfeffer WT and 19 others (2014) The Randolph glacier inventory: a globally complete inventory of glaciers. J. Glaciol., $\mathbf{6 0}(221)$, 537-552 (doi: 10.3189/2014JoG13J176)

Rabatel A, Dedieu JP and Vincent C (2005) Using remote-sensing data to determine equilibrium-line altitude and mass-balance time series: validation on three French glaciers, 1994-2002. J. Glaciol., 51(175), 539-546 (doi: 10.3189/172756505781829106)

Rabatel A, Letréguilly A, Dedieu J-P and Eckert N (2013) Changes in glacier equilibrium-line altitude in the western Alps from 1984 to 2010: evaluation by remote sensing and modeling of the morpho-topographic and climate controls. Cryosphere, 7(5), 1455-1471 (doi: 10.5194/tc-7-1455-2013)

Rasmussen LA (2013) Meteorological controls on glacier mass balance in High Asia. Ann. Glaciol., 54(63), 352-359 (doi: 10.3189/2013AoG63A353)

Sangewar CV and Shukla SP (2009) Inventory of the Himalayan glaciers: a contribution to the International Hydrological Programme. Special Publication No. 34, Geological Survey of India, Govt. of India.

Shea JM and Immerzeel WW (2016) An assessment of basinscale glaciological and hydrological sensitivities in the Hindu Kush- Himalaya. Ann. Glaciol., 57(71), 308-318 (doi: 0.3189/ 2016AoG71A073)

Shea JM, Immerzeel WW, Wagnon P, Vincent C and Bajracharya S (2015) Modelling glacier change in the Everest region, Nepal Himalaya. Cryosphere, 9(3), 1105-1128.

Six D and Vincent C (2014) Sensitivity of mass balance and equilibrium-line altitude to climate change in the French Alps. J. Glaciol., 60(223), 867-878 (doi: 10.3189/2014JoG14J014)

Tawde SA, Kulkarni AV and Bala G (2016) Estimation of glacier mass balance on a basin scale: an approach based on satellite-derived snowlines and a temperature index model. Curr. Sci., 111(12), 1977-1989 (doi: 10.18520/cs/v111/i12/1977-1989)

Taylor JR (1982) An introduction to error analysis: the study of uncertainties in physical measurements, $2^{\text {nd }}$ edn. University Science Books, California.

Thibert E, Eckert N and Vincent C (2013) Climatic drivers of seasonal glacier mass balances: an analysis of 6 decades at Glacier de Sarennes (French Alps). Cryosphere, 7(1), 47-66 (doi: 10.5194/ tc-7-47-2013)

Vijay S and Braun M (2016) Elevation change rates of glaciers in the Lahaul-Spiti (western Himalaya, India) during 2000-2012 and 2012-2013. Remote Sens., 8(12), 1038, 1-16 (doi: 10.3390/ rs8121038)

Vincent (2002) Influence of climate change over the $20^{\text {th }}$ Century on four French glacier mass balances. J. Geophys. Res., 107(19), 4375 (doi: 10.1029/2001JD000832)

Vincent C and 10 others (2013) Balanced conditions or slight mass gain of glaciers in the Lahaul and Spiti region (northern India, Himalaya) during the nineties preceded recent mass loss. Cryosphere, 7(2), 569-582

Woul MD and Hock R (2005) Static mass-balance sensitivity of Arctic glaciers and ice caps using a degree-day approach. Ann. Glaciol., 42, 217-224

Zemp M, Hoelzle M and Haeberli W (2007) Distributed modelling of the regional climatic equilibrium line altitude of glaciers in the European Alps. Glob. Planet. Change, 56(1-2), 83-100 (doi: 10.1016/j.gloplacha.2006.07.002)

Zemp $M$ and 5 others (2008) Global Glacier Changes: facts and figures. In UNEP, World Glacier Monitoring Service Switzerland. 